\title{
Flypaper Effect of Intergovernmental Transfers and Incentives to Improve Own-Source Revenue Mobilization of Local Governments in the Central Region of Ghana
}

\author{
Christopher Dick-Sagoe ${ }^{1}$, Ernest Ngeh Tingum ${ }^{2 *}$ \\ ${ }^{1}$ Department of Political and Administrative Studies, University of Botswana (UB), Gaborone, Botswana \\ ${ }^{2}$ Department of Economics, University of Namibia (UNAM), Windhoek, Namibia \\ Email: dicksagoe@gmail.com, sagoecd@ub.ac.bw, *etingum@unam.na, *ngehernest@gmail.com
}

How to cite this paper: Dick-Sagoe, C., \& Tingum, E. N. (2021). Flypaper Effect of Intergovernmental Transfers and Incentives to Improve Own-Source Revenue Mobilization of Local Governments in the Central Region of Ghana. Open Journal of Social Sciences, 9, 434-447.

https://doi.org/10.4236/jss.2021.98030

Received: May 17, 2021

Accepted: August 28, 2021

Published: August 31, 2021

Copyright $\odot 2021$ by author(s) and Scientific Research Publishing Inc. This work is licensed under the Creative Commons Attribution International License (CC BY 4.0).

http://creativecommons.org/licenses/by/4.0/

(c) (i) Open Access

\begin{abstract}
Flypaper effect and the fiscal interest model have been employed to explain the fiscal behaviour of local government officials in the Central Region of Ghana. Central government transfers or grants have taken dominion over local government expenditure compared with own-source revenues, creating a situation known as the flypaper effect. Using panel data for 17 local governments from 2008 to 2015, the study examined the fiscal behavior of local government officials when presented with intergovernmental fiscal transfers and own-source revenues. The analysis employed the panel data analysis of fixed effects and random effects. However, given the optimal unbiased results, the Generalized Least Squares (GLS) is estimated to account for heteroscedasticity and serial autocorrelation. The results show that central government transfers contribute more to local government expenditure than local governments' own-source revenues. This situation confirms the flypaper effect on local governments in the Central Region, thus explaining the fiscal behavior of the local governments. Whilst the system of intergovernmental transfers in Ghana has been very successful in directing resources towards the local governments, it may be counterproductive in encouraging the local governments in raising their revenue at the local level as demonstrated by the presence of the flypaper effect.
\end{abstract}

\section{Keywords}

Flypaper Effect, Fiscal Transfer, Local Governments, Fiscal Interest, Own-Source Revenue, Intergovernmental Fiscal Transfer 


\section{Introduction}

Ghana's intergovernmental transfers from the Central Government to the Local Governments (called the District Assemblies' Common Fund (DACF)) was established by Article 252 of the 1992 constitution of the Republic Ghana. Being a Development Fund, the DACF uses not less than 5 per cent of the Ghana's wealth set aside and shared among all the local governments according to a sharing formula approved by the Parliament of the Republic of Ghana. The aim of the intergovernmental transfers, as stipulated within the sharing formula, is the promotion of two issues: First, to provide adequate and equitable distribution of local public services within local governments jurisdictions to benefit all the citizens. Second, to promote the mobilization of local governments own-source revenues. To support this second point, the sharing formula rewards improvement in own-source revenue mobilization, as captured under responsive factor, reflecting that the DACF is to promote improvement in own-source revenue generation. This study derives its argument from this second point.

In its real sense, and in line with the public finance argument, intergovernmental fiscal transfers were instituted to address the economic objective of correcting structural (economic) imbalances within an economy (Oates, 2003; Rao \& Singh, 1998). In most cases, intergovernmental transfers have been used as an effective instrument in correcting revenue and expenditure imbalances between the Central and the Local Governments (known as the vertical imbalance) and revenue and expenditure imbalances among the local governments themselves (known as horizontal imbalance). This seeks to promote fiscal equity among local governments, thus, offsetting inter-jurisdictional spill-overs (Gamkhar \& Shah, 2007; Bahl et al., 2020). For instance, by virtue of their locations, some local governments are well-positioned financially than others in terms of collecting own-source revenue. So intergovernmental fiscal transfers are meant to fill this gap (economic imbalance among the local governments themselves). Further, with the mandate to ensure the total development of their respective jurisdictions through the provision of adequate local public service, intergovernmental fiscal transfers were instituted to support local governments with adequate financial resources to achieve their developmental mandate (Dick-Sagoe, 2013). Again, local governments have different financial capacity reflected in different levels of own-source revenue generation. Therefore, intergovernmental fiscal transfers seek to balance these differences, so that service provision will be equitably distributed within the country (Dick-Sagoe, 2020).

From these views, it is therefore clear that intergovernmental transfers are meant to financially assist local governments in order to ensure equitable distribution of local services for the benefit of all citizens (Dick-Sagoe \& Asare-Nuamah, 2021). Hence, the absence of intergovernmental transfers to local governments may lead to huge variations in local public service delivery and a flight of mobile citizens from disadvantaged local jurisdictions (Levaggi \& Smith, 2003; Tiebout, 1956). However, this policy provision has resulted in a different thing as local governments globally have depended solely on intergovernmental transfers, thus 
eroding their constitutional given mandate to have local autonomy over their jurisdictions (Setyawan, 2011). This is to say that, instead of being a supplementary fund to encourage own-source revenue generation, intergovernmental transfers have rather replaced own-source revenue generation ability of local governments which is contrary to the policy provision of intergovernmental transfers (Zigiene, 2012). Studies have argued that allowing intergovernmental transfers to reduce own-source revenue mobilization erodes local autonomy of local governments and makes local governments an agent for political manipulation of the Central Government, thus re-centralizing the decentralized bodies to serve the political interest of the Central government (Dick-Sagoe, 2013; Kang \& Setyawan, 2012; Poschl \& Weingast, 2013; Rao \& Singh, 1998). This is the main motivation for the conduct of this study.

\section{Review of Literature}

The two interrelated theories which support this study, the flypaper effect and the fiscal interest model, argue that intergovernmental transfers attract the interest of local government officials to be more reliant on such transfers other than improving own-source revenue generation. In this sense, local people become passive actors in local decisions on how local revenues should be spent. This is to say that dependence on own-source revenue to finance local expenditure, other than intergovernmental transfers, forces the local people to take active part in decisions concerning the local revenue expenditure.

\subsection{Flypaper Effects}

The flypaper effect, a concept from the field of public finance, argues that intergovernmental transfers to local governments increases the level of local public spending more than an equivalent increase in own-source revenue (Dahlby \& Ferede, 2016). The flypaper effect results when a dollar of exogenous grantsin-aid leads to significantly greater public spending than an equivalent dollar of citizen income (Aaberge \& Langørgen, 1997; Inman, 2008; Moisio, 2003). More so, flypaper effect is a condition in which the stimulus of local spending caused by changes in central government transfers has a greater effect than the stimulus that caused by changes in local income (Mattos et al., 2011; Oates, 2003).

On the theoretical effect of flypaper effect on local governments, Niskanen (2019) argues that flypaper effects incentives local bureaucrats, uses their strong position in public decision making to increase local expenditure based on their power. This leads to bureaucrats' behaviour that freely spends intergovernmental transfers rather than focusing on increasing local own-source revenues because bureaucrats possess more information on revenue sources.

\subsection{Fiscal Interest Model}

This model postulates that local government officials are influenced by policies that relax their soft budget constraint (Wallis \& Sylla, 1994). Put differently, officials of local government are bias towards policies which seek to increase their 
revenues. This means that the presence of large amount and regular flow of intergovernmental transfers to local governments increases their revenue and make them bias towards such transfers and this makes them focus less on the mobilisation of other revenue sources, such as own-source revenues. To support his claim, Poschl \& Weingast (2013) attribute the failure of local governments' own-source revenue mobilization to the design of the fiscal system; the specific arrangement of tax and transfers to local governments (in this case intergovernmental transfers). This design (that is intergovernmental transfers) therefore shapes the policy choices and local service provision performance of local governments.

To throw more light, Poschl \& Weingast (2013) further contend that intergovernmental transfers directly affect incentives and interest of local government officials, thereby affecting their interest to increase own-source revenue mobilisation to finance local development expenditure. When this situation sets in, (Sirenko et al., 2018), it automatically erodes the local autonomy of local governments, as local governments become accountable to the central government than the local people for which they are supposed to serve. The situation results in a case where local governments expenditure does not reflect local needs and priorities as argued by Oates (2003) in his popular allocative efficiency principle.

Additionally, Rao \& Singh (1998) argues that central transfers serve two purposes, economic and political. The economic purpose, which is the provision of public services, is good. However, the political purpose is considered bad. The reason is that the Central government being economically rational and self-interesting (self-aggrandizing) uses such transfers to lure local governments to serve as their agents to pursue their political agenda. Once local governments become the agent of the Central government, local governments lose the autonomy they have over their locality.

\section{Methodology}

To test and validate the hypothesis, and achieve the objective of this study, we use panel data estimation techniques and the Generalized Least Squared (GLS) method. This section discusses the data and variables used, the method of analysis, results and the post estimation tests to correct for serial correlation and heteroscedasticity in the panel data.

\subsection{Data Source}

The analysis used longitudinal data for the period 2008 to 2015. Data are obtained from the archives of the office of the District Assembly Common fund administrator and the archives of the Controller and Accountant General's office, Accra-Ghana. The data sources provide information on central government expenditure or transfers to local governments, local governments own revenues and other characteristics. The current study uses data for the period 2008 to 2015 and the pooled data consist of a total of 136 observations. The sample, composed of 17 local governments was defined according to the availability of 
data for those areas. The sample constitutes $74 \%$ of the total local governments in the Central Region of Ghana. For statistical estimates, the sample periods began in 2008, which makes it possible to distinguish compulsory and discretionary intergovernmental transfers. Thus, the sample size is a balanced panel, meaning that, for each local government, same numbers of data points are used. New local governments created during the study period were excluded from the sample.

\subsection{Model Specification and Variables Used}

The main purpose of the analysis is to estimate the impact of intergovernmental transfer to local government expenditure as well as examine the existence of the flypaper effect phenomenon. Therefore, the estimation of the different specifications has been done on the bases of panel data estimators - fixed/random effects and generalized least squares (GLS). In recent years, panel data modelling has been highly utilized in the empirical analysis of intergovernmental transfers due to some of its advantages over cross-sectional and time-series data. Some of these advantages have been enumerated in Hsiao (2003) as follows: First, panel data models account for unobserved heterogeneity among the local governments. Second, panel data estimation reduce collinearity among covariates, improving efficiency, reliability and stability of econometrics estimates, and identifying and measuring effects not detectable in a cross-sectional method (Greene, 2012). Third, panel analysis has the ability to accommodate the possibility of the impact or influence of other variables (i.e. a difference across cross-sectional units) that may be excluded in other analysis (Hsiao, 2007). Fourth, Panel data are better able to identify and measure effects that are simply not detectable in pure cross-section or pure time-series data (Xu et al., 2007). Therefore, failure to use appropriate panel techniques may lead to models misspecification and errors resulting in biased estimates and unreliable diagnostic statistics (Min, 2019).

The empirical model uses a double-logarithmic equation which gives a straightforward interpretation to the coefficients (elasticities). A conventional econometric model for the estimation is specified as follows:

$$
\log \text { totexp }_{i t}=\beta_{0}+\beta_{1} \log \text { transfers }_{i t}+\beta_{2} \log \text { ownrev }_{i t}+\alpha_{i}+\mu_{i t}
$$

where totexp is the total expenditure by the municipalities, transfers is the grants/transfers that municipalities receive from the government, ownrev is the revenue raised the municipalities. The subscript $i$ denotes the municipalities and $t$ time. $\alpha_{i}$ are the individual errors while $\mu_{i t}$ are the random errors, which are the errors associated with the $i^{\text {th }}$ group in period $(t)$ The variables used in the study are measured in per-capita terms at 2015 prices, which are deflated using the consumer price index. Table 1 shows the descriptive statistics for the variables used while Appendix (Table A1, Table A2 and Table A4) show the definitions and sources of the variables as well as summary statistics of variables for the local governments in nominal values (Ghana Cedis) for the period 2008-2015. As mentioned in the foregoing discussion, fixed effects (FE) and random effect (RE) 
models for panel data are used in the analysis. These models are potentially valid in the estimation of the panel model in Equation (3) with unobserved local governments heterogeneity. Therefore, either FE or RE models may be valid models to be used based on the Hausman specification test results. In order to make an appropriate decision between the FE and RE model, a formal test of Hausman (1978) specification is estimated.

The null hypothesis of Hausman test is as follows: $\mathrm{H}_{0}$ : random effects are more consistent; against the alternative hypothesis: $\mathrm{H}_{1}$ : only the fixed effect estimates are consistent. Thus, if the Hausman test statistic is significant, then the null hypothesis is rejected. In this case, the fixed effect model is consistent is employed in the analysis. If the test statistic is insignificant, the null hypothesis cannot be rejected, and the random effects estimators should be used. The results of the Hausman test statistics are presented in Table 2.

The Hausman test in Table 2 presents the results for two models. Model 1 which is estimated without the inclusion of time and year dummies, while model 2 includes the time and year dummies. The chi2 and probability values of the test statistics indicate that the null hypothesis can be rejected for the models. Therefore, FE estimators are more consistent and were applied in the analysis. This test statistic supports the theoretical justification because of the inexistence of time-invariant independent variables in the model and the application of the FE (differencing out time-invariant variables) in the analysis does not exclude any important variables (Sijabat, 2016).

Table 1. Descriptive statistics using log of variables.

\begin{tabular}{cccc}
\hline Statistics & $\log ($ totexp $)$ & $\log ($ transfers $)$ & $\log ($ ownrev $)$ \\
\hline Mean & 14.625 & 14.377 & 12.625 \\
Median & 14.727 & 14.507 & 12.606 \\
Maximum & 16.142 & 18.015 & 15.863 \\
Minimum & 11.669 & 11.471 & 9.0154 \\
Std. Dev. & 0.6935 & 0.9051 & 1.0587 \\
Skewness & -1.3592 & -0.6318 & 0.1215 \\
Kurtosis & 7.2072 & 5.6665 & 3.9490 \\
Jarque-Bera & 142.18 & 49.339 & 5.4381 \\
Probability & 0.0000 & 0.0000 & 0.0659 \\
Sum & 1989.02 & 1955.25 & 1716.94 \\
Sum Sq. Dev. & 64.9178 & 110.587 & 151.323 \\
Observation & 136 & 136 & 136 \\
\hline
\end{tabular}

Source: Authors' Calculation.

Table 2. Hausman test results.

\begin{tabular}{ccccl}
\hline Model & Test & Chi $^{2}$ & Prob $>$ chi $^{2}$ & Decision \\
\hline 1 & Random Effect Vs Fixed Effect & 6.55 & 0.0378 & Reject $\mathrm{H}_{0}$ \\
2 & Random Effect Vs Fixed Effect & 21.81 & 0.0021 & Reject $\mathrm{H}_{0}$ \\
\hline
\end{tabular}

Source: Authors' Calculation. 
Since panel data has both a cross-sectional and a time-series dimension, the data analysis usually encounter heteroscedasticity and serial correlation (Beck, 2001; Hsiao, 2007). Some of the causes of these problems are widely discussed in Beck (2001) as follows: First, local governments may have their own error variances pertaining to the unique local governments characteristics; second; error (shocks) in one local government area my likely spillover to another area within the same region. This may cause serial autocorrelation if the shocks from one local government correlate with shocks from another local government in the same year; third, within the same local government, shocks or errors in the current years maybe correlated with errors in the past period or periods. Based on these problems pertaining to the nature of time-series-cross-sectional data of panel models, this study conducted the heteroscedasticity test using the Modified Wald Test for Heteroscedasticity (Baum, 2001), and serial autocorrelation tests using Wooldridge Test for Autocorrelation (Drukker, 2003), before analyzing and interpreting the results of the panel models. These tests were undertaken on fixed effects estimation and the results are presented in Table 3.

The interpretation of the results in Table 3 are based on the value of the Prob > F statistics. For the heteroscedasticity test, the null hypothesis is stated as: $\mathrm{H}_{0}$ : errors are homoscedastic (no heteroscedasticity); against the alternative hypothesis: $\mathrm{H}_{1}$ : errors are heteroscedastic. According to the F-statistics of the modified Wald test in all models, the null hypothesis of no heteroscedasticity is rejected; indicating that there is heteroscedasticity in the models.

The Wooldridge test for the existence/non-existence of serial correlation was conducted using the null hypothesis: $\mathrm{H}_{0}$ : No autocorrelation of errors; against the alternative hypothesis; $\mathrm{H}_{1}$ : Autocorrelation of errors. Results from the Wooldridge test rejected the null hypothesis and concluded on the existence of serial correlation in the error terms of the panel models. The existence of heteroscedasticity and serial autocorrelation necessitates the use of the Generalized Least Square (GLS) estimator in the analysis. In the GLS model, the intercept is an individual specific disturbance (Greene, 2012). The GLS is estimated using Equation (1) above.

Table 3. Results for panel heteroscedasticity and autocorrelation.

\begin{tabular}{|c|c|c|c|c|c|}
\hline \multicolumn{6}{|c|}{ Modified Wald test for heteroscedasticity in FE model } \\
\hline Model & & & & & Decision \\
\hline \multirow[t]{2}{*}{1} & $\mathrm{~F}(2,117)$ & 57.47 & $\operatorname{chi}^{2}(17)$ & 7990.53 & \multirow{2}{*}{ Heteroscedastic } \\
\hline & Prob $>$ F & 0.0000 & Prob $>\mathrm{chi}^{2}$ & 0.0000 & \\
\hline \multirow[t]{2}{*}{2} & $F(9,110)$ & 15.62 & $\operatorname{chi}^{2}(17)$ & 1144.45 & \multirow{2}{*}{ Heteroscedastic } \\
\hline & Prob $>$ F & 0.0000 & Prob $>\mathrm{chi}^{2}$ & 0.0000 & \\
\hline \multicolumn{6}{|c|}{ Wooldridge test for autocorrelation in panel data } \\
\hline \multirow[t]{2}{*}{1} & $\mathrm{~F}(2,16)$ & 4.56 & $\mathrm{~F}(1,16)$ & 3.484 & \multirow{2}{*}{ Serial Correlation } \\
\hline & Prob $>$ F & 0.0270 & Prob $>$ F & 0.0804 & \\
\hline \multirow[t]{2}{*}{2} & $F(2,16)$ & 8.37 & $\mathrm{~F}(1,17)$ & 11.726 & \multirow{2}{*}{ Serial Correlation } \\
\hline & Prob $>F$ & 0.0082 & Prob $>F$ & 0.0006 & \\
\hline
\end{tabular}

Source: Authors' calculation. 


\section{Results and Discussions}

The analysis employed the panel Generalized Least Squares (GLS) estimator in the two models. This estimator produce optimal unbiased results because it account of heteroscedasticity and serial correlation in panel data (Hansen, 2007; Muthama Musau, 2015). The GLS results are presented in Table 4. The table reports the coefficients and t-statistics for the 2 models in the panel analysis.

From Table 4, column 1 reports the GLS panel result without the time and year dummies while the results in column 2 include the dummies. With respect to the control variables, they are all positive and significant. The regression analysis is used to determine the effect of each of the independent variables on the dependent variable i.e. the effects of government transfer (transfers) and local own revenue (ownrev) on total expenditure (totexp). Overall, using the prob > $\mathrm{chi}^{2}$, the regressions were found to be significant. Statistical Wald $\mathrm{chi}^{2}$, which shows the overall significance of the model, indicates that the independent variables together, explain the variance in the dependent variable. The results for FE and RE presented in Table A3.

The coefficient of transfers and own revenue are positive and significant at $1 \%$ level. This suggests that a $1 \%$ change in government transfer will cause between a $43.3 \%$ and $47.0 \%$ change on local total expenditure respectively when the two models are used; controlling for the years' effects (year dummies) and excluding the years' dummies respectively. This means the higher the current year's transferred funds, the greater the local expenditure in the particular year. In the case of own revenue, a $1 \%$ increase changes local total expenditure by $21.2 \%$ to $30.6 \%$ respectively holding other factors constant. This means the higher the current year's local own revenue, the greater the local expenditure current year. Similar positive and significant results were obtained by (Ğbafi \& Saruçş, 2004; Sijabat, 2016).

Table 4. Parameter estimates of GLS model.

\begin{tabular}{ccc}
\hline Variable & Model 1 & Model 2 \\
\hline $\log ($ transfers $)$ & $0.470^{* * *}$ & $0.433^{* * *}$ \\
& $(0.047)$ & $(0.059)$ \\
$\log ($ ownrev $)$ & $0.306^{* * *}$ & $0.212^{* * *}$ \\
& $(0.040)$ & $(0.047)$ \\
Constant & $4.008^{* * *}$ & $5.547^{* * *}$ \\
& $(0.905)$ & $(1.033)$ \\
Year Dummy & NO & YES \\
Wald chi & \\
Prob $>$ chi $^{2}$ & 138.10 & 178.59 \\
Log likelihood & 0.000 & 0.000 \\
Number of ID & -95.031 & -85.662 \\
Observations & 17 & 17 \\
\hline
\end{tabular}

Source: Authors' calculation. Note: ${ }^{* *}$ shows significance level at $1 \%$ level, while values in parenthesis represent standard errors. 
As concerns the flypaper effect phenomenon, the study compared the coefficients of each of the control variables when all the variables (transferred funds and own revenue) are regressed simultaneously while controlling for the years' effects. The coefficient of transferred funds is greater than the coefficient of own revenue for the entire study period. This shows that the magnitude of transferred funds is significantly more powerful in predicting local total expenditure than own revenue. This situation confirms the flypaper effect on local governments in the Central Region, thus explaining the fiscal behavior of the local governments. When the flypaper effect occurs, there is a likelihood for the re-centralization of decentralized local governments. Thus, local governments which have relatively high vertical imbalances will likely have larger government transfers (Sijabat, 2016). In short, the response of the local government to central government transfer is greater than their local own revenue is the so-called flypaper effect. According to Gorodnichenko (2001) flypaper effect phenomenon can occur in two versions; first, it leads to an increase in local taxes and excessive government budget spending, and second, it leads to a higher elasticity of local government expenditure to transfer rather than the elasticity of local government expenditure to local tax revenue. Therefore, this study supports the second version of the flypaper effects.

The study has some limitations; first, only two independent variables were used in the model based on the availability of data. Control variables like population and income were thought of during the estimation but due to lack of data on these variables, they were not included in the estimation.

Second, the period of study is limited to 8 years from 2008 to 2015. This is based on the fact that intergovernmental transfers could be distinguish between compulsory and discretionary transfers. More so, some of the new local governments that were created within the time period were not included in the analysis due to the unbalanced nature of the data.

\section{Conclusion}

This paper has argued that local governments which depend on own-source revenue are more autonomous than those that depend on central governments transfers. By autonomous, local governments will have the freedom to regulate their governments and be able to fund their recurrent and development expenditure from own-source revenues. In this case, they have less chance to be controlled and used as the central government's agents to achieve their political aims. With the absence of (or less) political control, local governments can then focus on their development roles and are most likely to provide goods and services which meets the needs of the local people they serve. This meets the allocative efficiency principle advocated by Oates (2003).

Again, intergovernmental transfers making a bulk contribution to local expenditure compared to local own-source revenues creates incentives to local bureaucrats, who have powers over local policies and are more knowledgeable on 
local finances of the local governments to increase local expenditure without increasing local own-source revenue mobilisation. This lures local bureaucrats to be more inclined to satisfy the conditions necessary to attract more intergovernmental transfers, which are tied to the political interest of the Central Government, rather than the conditions and needs of the local people for which they serve (Rao \& Singh, 1998). Thus eroding the essence of decentralisation, which is to encourage local autonomy.

This paper investigates the impact of government transfers and own revenue on local government expenditure and also to analyse the possibility of the flypaper effects on the local governments in the Central Region of Ghana. Using data for 17 local governments in the Central Region of Ghana from 2008 to 2015, the study employed a panel data approach for the analysis. While accounting for heteroscedasticity and autocorrelation of residuals in the panel GLS analysis, the results show evidence of intergovernmental transfers to local governments accounting for more local government expenditure than own source revenue, depicting evidence of a flypaper effect.

Whilst the system of intergovernmental transfers in Ghana has been very successful in directing resources towards the local governments, it may be counterproductive in encouraging the local governments in raising their own revenue at the local level as demonstrated by the presence of the flypaper effect. Local bureaucrats are more likely to follow the instructions of the central government to attract more intergovernmental transfers rather than improving the mobilization of own-source revenues. This in effect, affects the incentives to mobilize ownsource revenues at the local governments level.

\section{Authors' Contributions}

The authors listed have made a substantial, direct and intellectual contribution to the work, and approved it for publication.

\section{Conflicts of Interest Statement}

The authors declare that the research was conducted in the absence of any commercial or financial relationships that could be construed as a potential conflict of interest.

\section{References}

Aaberge, R., \& Langørgen, A. (1997). Fiscal and Spending Behavior of Local Governments: An Empirical Analysis Based on Norwegian Data. Discussion Papers No. 196, Statistics Norway, Research Department.

Bahl Jr., R. W. (2020). The Architecture of Intergovernmental Transfers: Principles and Practice in Low- and Middle-Income Countries. In S. Yilmaz, \& F. Zahir (Eds.), Intergovernmental Transfers in Federations (pp. 7-29). Edward Elgar Publishing.

Baum, C. F. (2001). Residual Diagnostics for Cross-Section Time Series Regression Models. The Stata Journal: Promoting Communications on Statistics and Stata, 1, 101-104. https://doi.org/10.1177\%2F1536867X0100100108 
Beck, S. (2001). Autoregressive Conditional Heteroscedasticity in Commodity Spot Prices. Journal of Applied Econometrics, 16, 115-132. https://doi.org/10.1002/jae.591

Dahlby, B., \& Ferede, E. (2016). The Stimulative effects of Intergovernmental Grants and the Marginal Cost of Public Funds. International Tax and Public Finance, 23, 114-139. https://doi.org/10.1007/s10797-015-9352-5

Dick-Sagoe, C (2020). Decentralization for Improving the Provision of Public Services in Developing Countries: A Critical Review. Cogent Economics and Finance Journal, 8, Article ID: 1804036. [Peer Review Journal] https://doi.org/10.1080/23322039.2020.1804036

Dick-Sagoe, C., \& Asare-Nuamah, P. (2021). Public Choice and Decentralised Healthcare Service Delivery in Lesotho: Assessment of Efficient Service Delivery from Service Providers and Users. Cogent Social Sciences (Scopus).

Dick-Sagoe. (2013). Performance and Challenges of Internally Generated Revenue Mobilization of the Abura-Asebu-Kwamankese District Assembly for Local Level Development. University of Cape Coast.

Drukker, D. M. (2003). Testing for Serial Correlation in Linear Panel-data Models. The Stata Journal: Promoting Communications on Statistics and Stata, 3, 168-177. https://doi.org/10.1177\%2F1536867X0300300206

Gamkhar, S., \& Shah, A. (2007). The Impact of Intergovernmental Fiscal Transfers: A Syntesis of the Conceptual and Empirical Literature. In R. Boadway, \& A. Shar (Eds.), Intergovernmental Fiscal Transfers: Principles and Practice (pp. 225-528). World Bank.

Ğbafi, S., \& Saruçş, N. T. (2004). Intergovernmental Transfers and the Flypaper Effect in Turkey. Turkish Studies, 5, 79-92. https://doi.org/10.1080/1468384042000228602

Gorodnichenko (2001). Effects of Intergovernmental Aid on Fiscal Behavior of Local Governments: The Case of Ukraine. Master Thesis, National University of Kyiv-Mohyla Academy.

Greene, W. W. H. (2012). Econometric Analysis (7th ed.). Prentice Hall.

Hansen, C. B. (2007). Generalized Least Squares Inference in Panel and Multilevel Models with Serial Correlation and Fixed Effects. Journal of Econometrics, 140, 670-694. https://doi.org/10.1016/j.jeconom.2006.07.011

Hausman, J. A. (1978). Specification Tests in Econometrics. Econometrica, 46, 1251-1271.

Hsiao, C. (2003). Analysis of Panel Data (2nd ed.). Cambridge University Press. https://doi.org/10.1017/CBO9780511754203

Hsiao, C. (2007). Panel Data Analysis-Advantages and Challenges. TEST, 16, 1-22. https://doi.org/10.1007/s11749-007-0046-x

Inman, R. P. (2008). The Flypaper Effect. Working Paper No. 14579, National Bureau of Economic Research, Inc. https://doi.org/10.3386/w14579

Kang, Y., \& Setyawan, D. (2012). Intergovernmental Transfer and the Flypaper EffectEvidence from Municipalities/Regencies in Indonesia. Paper No. 12-06, KDI School of Pub Policy \& Management. https://doi.org/10.2139/ssrn.2065638

Levaggi, R., \& Smith, P. C. (2003). Decentralization in Health Care: Lessons from Public Economics. In P. C. Smith, L. Ginnelly, \& M. Sculpher (Eds.), Health Policy and Economics (pp. 223-247). Open University Press.

Mattos, E., Rocha, F., \& Arvate, P. (2011). Flypaper Effect Revisited: Evidence for Tax Collection. Estudos Econômicos (São Paulo), 41, 239-267. https://doi.org/10.1590/S0101-41612011000200002

Min, C. (2019). Models for Panel Data. In C. Min (Ed.), Applied Econometrics. Routledge. https://doi.org/10.4324/9780429024429-7 
Moisio, A. (2003). The Flypaper Effect: Evidence from Finnish Municipalities. European Research in Regional Science (pp.153-172). Pion Limited.

Muthama Musau, V. (2015). Modeling Panel Data: Comparison of GLS Estimation and Robust Covariance Matrix Estimation. American Journal of Theoretical and Applied Statistics, 4, 185-191. https://doi.org/10.11648/j.ajtas.20150403.25

Niskanen, W. A. (2019). 22. The Peculiar Economics of Bureaucracy. In R. Amacher, R. D. Tollison, \& T. D. Willett (Eds.), The Economic Approach to Public Policy (pp. 349-361). Cornell University Press. https://doi.org/10.7591/9781501741012-024

Oates, W. E. (2003). An Essay on Fiscal Federalism. In M. Baimbridge, \& P. Whyman (Eds.), Fiscal Federalism and European Economic Integration (pp. 13-47). Routledge.

Poschl, C., \& Weingast, B. R. (2013). The Fiscal Interest Approach: The Design of Tax and Transfer Systems. SSRN Electronic Journal. https://doi.org/10.2139/ssrn.2370560

Rao, G. V., \& Singh, N. (1998). Intergovernmental Transfers: Rationale, Design and Indian Experience. Working Paper, Centre for International Development, Stanford University.

Setyawan, D. (2011). Intergovernmental Transfer in Indonesia and the Flypaper Effect Phenomenon. KDI School.

Sijabat, R. (2016). Panel Analysis on the Association of Fiscal Decentralisation and the Size of Government in Indonesia. Journal of Economics, Business and Management, 4, 206-214. https://doi.org/10.7763/JOEBM.2016.V4.392

Sirenko, N. M., Baryshevskaya, I. V., Poltorak, A. S., \& Shyshpanova, N. O. (2018). State and Tendencies of Intergovernmental Regulation in Ukraine in Conditions of Fiscal Decentralization. Financial and Credit Activity: Problems of Theory and Practice, 2, 157-164.

Tiebout, C. M. (1956). A Pure Theory of Local Expenditures. Journal of Political Economy, 64, 416-424. https://doi.org/10.1086/257839

Wallis, J. J., \& Sylla, R. E. (1994). The Interaction of Taxation and Regulation in Nineteenth-Century U.S. Banking. In C. Goldin, \& G. D. Libecap (Eds.), The Regulated Economy: A Historical Approach to Political Economy (pp. 121-144). University of Chicago Press.

Xu, H., Hwan Lee, S., \& Ho Eom, T. (2007). Introduction to Panel Data Analysis. In Miller/Handbook of Research Methods in Public Administration (pp. 571-590). https://doi.org/10.1201/9781420013276.ch32

Zigiene, G. (2012). The Importance of Functions Assignment for the Intergovernmental Fiscal Relations. Journal of Business Management, 5, 112-125. 


\section{Appendix}

Table A1. Definition and sources of variables.

\begin{tabular}{lllll}
\hline Variables & Symbol & Definition & Unit & Source \\
\hline Total expenditure & totexp & Total expenditure by the municipalities & Million/Gh $₫$ & $\begin{array}{l}\text { Archives from the District Assembly } \\
\text { Common fund }\end{array}$ \\
Transfers & Transfers & $\begin{array}{l}\text { Grants/transfers that } \\
\text { municipalities receive } \\
\text { from the government }\end{array}$ & Million/Gh $₫$ & $\begin{array}{l}\text { Archives from the District Assembly } \\
\text { Common fund }\end{array}$ \\
Own Revenue & ownrev & $\begin{array}{l}\text { Revenue raised the } \\
\text { municipalities }\end{array}$ & Million/Gh $₫$ & $\begin{array}{l}\text { Archives from the District Assembly } \\
\text { Common fund }\end{array}$ \\
\hline
\end{tabular}

Table A2. Summary statistics of variables for the local governments in nominal values (Ghana Cedis) for the period 2008-2015.

\begin{tabular}{|c|c|c|c|c|c|c|c|c|c|c|c|c|}
\hline & \multicolumn{4}{|c|}{ Total Expenditure } & \multicolumn{4}{|c|}{ Transfers } & \multicolumn{4}{|c|}{ Owned Revenue } \\
\hline & Mean & Std. Dev. & Min. & $\operatorname{Max}$ & Mean & Std. Dev. & Min. & $\operatorname{Max}$ & Mean & Std. Dev. & Min. & $\operatorname{Max}$ \\
\hline Cape Coast & $4,129,479$ & $3,297,863$ & $1,321,627$ & $1.02 \mathrm{e}+07$ & $2,441,212$ & $1,888,859$ & $754,757.1$ & $6,071,676$ & $1,688,910$ & $2,506,571$ & $77,627.04$ & $7,748,625$ \\
\hline Swedru & $3,629,884$ & $862,276.4$ & $2,468,355$ & $4,683,503$ & $2,686,253$ & $1,069,127$ & 685,592 & $3,761,329$ & $1,103,680$ & $1,007,533$ & $331,855.2$ & $3,406,567$ \\
\hline Dunkwa & $1,892,311$ & $1,176,326$ & $155,852.9$ & $3,992,360$ & $2,011,912$ & $1,610,188$ & $372,836.5$ & $4,636,993$ & $680,532.2$ & $700,541.7$ & $97,768.84$ & $1,950,564$ \\
\hline Saltpond & $4,183,594$ & $3,284,092$ & $1,716,939$ & $9,457,672$ & $2,704,458$ & $1,268,853$ & $1,357,562$ & $4,692,285$ & $557,360.6$ & $256,187.4$ & $209,691.5$ & 879,968 \\
\hline Winneba & $2,506,656$ & $1,235,935$ & $558,698.1$ & $4,180,016$ & $2,282,085$ & $1,795,206$ & $307,003.3$ & $5,607,973$ & $657,767.4$ & $776,833.4$ & $136,501.9$ & $2,443,881$ \\
\hline Elmina & $2,850,215$ & $986,402.6$ & $1,863,263$ & $4,545,478$ & $2,342,682$ & $1,194,558$ & $291,263.6$ & $4,292,547$ & $566,671.8$ & $701,657.2$ & $211,337.3$ & $2,292,223$ \\
\hline Assin Fosu & $3,352,720$ & $2,389,617$ & $1,158,191$ & $7,761,530$ & $1.06 e+07$ & $2.28 \mathrm{e}+07$ & $357,426.4$ & $6.67 e+07$ & $646,968.9$ & $852,825.1$ & $198,924.3$ & $2,743,130$ \\
\hline Twifo Praso & $1,886,124$ & $1,185,055$ & $970,790.6$ & $3,864,494$ & $1,540,287$ & $1,306,037$ & $462,139.3$ & $3,785,603$ & $376,298.5$ & $106,049.3$ & $221,081.2$ & $527,487.9$ \\
\hline A. Beraku & $2,536,491$ & $1,230,535$ & $701,747.2$ & $4,904,719$ & $1,977,395$ & $1,274,551$ & $462,815.1$ & $4,902,416$ & $620,323.8$ & $386,874.7$ & $263,483.6$ & $1,330,260$ \\
\hline Diaso & $2,770,244$ & $1,491,315$ & $836,461.4$ & $5,271,819$ & $2,422,559$ & $1,334,614$ & $818,134.1$ & $4,761,356$ & $183,662.6$ & $126,795.6$ & $17,424.85$ & $396,548.8$ \\
\hline Apam & $3,110,907$ & $1,019,777$ & $1,202,889$ & $4,354,443$ & $2,578,634$ & $1,408,176$ & $198,061.5$ & $3,951,529$ & 535,330 & $1,003,206$ & $82,034.12$ & $3,008,154$ \\
\hline A. Dunkwa & $1,697,310$ & $655,160.8$ & $842,185.9$ & $2,702,576$ & $1,490,037$ & $850,623.2$ & $104,827.6$ & $2,602,893$ & $342,125.3$ & $404,957.2$ & $77,627.04$ & $1,193,051$ \\
\hline Nsaba & $1,898,686$ & $989,812.3$ & $1,005,379$ & $4,039,626$ & $1,542,960$ & $1,352,094$ & $958,89.22$ & $4,276,590$ & $253,459.1$ & $370,984.2$ & $30,789.7$ & $1,159,620$ \\
\hline Afransi & $2,024,755$ & $1,268,439$ & $161,525.4$ & $3,672,241$ & $1,558,522$ & $814,730.2$ & $212,399.5$ & $2,409,771$ & $454,193.5$ & $612,795.5$ & 8228.89 & $1,924,416$ \\
\hline Ajumako & $2,108,206$ & $979,512.5$ & $117,005.7$ & $3,339,093$ & $2,348,124$ & $736,336.5$ & $1,308,914$ & $3,296,274$ & $141,064.6$ & $68,947.42$ & $36,126.39$ & $244,805.5$ \\
\hline Nsuaem & $3,340,257$ & $667,891.3$ & $2,512,767$ & $4,214,735$ & $3,417,623$ & $677,865.3$ & $2,404,102$ & $4,535,931$ & $168,733.7$ & $63,468.18$ & $74,110.97$ & 278,900 \\
\hline Asikuma & $2,422,337$ & $1,042,075$ & $652,256.5$ & $3,836,506$ & $1,964,935$ & $1,184,870$ & $157,199.4$ & $3,554,504$ & $470,394.4$ & 904,949 & $92,718.51$ & $2,708,072$ \\
\hline
\end{tabular}

Source: Authors' calculations.

Table A3. Pair-wise Correlation Matrix for log of variables.

\begin{tabular}{cccc}
\hline & $\log ($ totexp $)$ & $\log ($ transfers $)$ & $\log ($ ownrev $)$ \\
\hline $\log ($ totexp $)$ & 1.0000 & & \\
$\log ($ transfers $)$ & $0.5391^{* * *}$ & 1.0000 & \\
& $(0.000)$ & $-0.1577^{*}$ & 1.0000 \\
$\log ($ ownrev $)$ & $0.3709^{* * *}$ & $(0.0667)$ & \\
& $(0.000)$ & & \\
\hline
\end{tabular}

Source: Authors' calculations. Note: ${ }^{\star * *}$ shows significance level at $1 \%$ level, while values in parenthesis represent standard errors. 
Table A4. Panel results for Pooled OLS, fixed effects and random effects models.

\begin{tabular}{|c|c|c|c|c|c|c|}
\hline \multirow{2}{*}{ Variables } & \multicolumn{2}{|c|}{ Pooled OLS } & \multicolumn{2}{|c|}{ Fixed Effects } & \multicolumn{2}{|c|}{ Random Effects } \\
\hline & 1 & 2 & 1 & 2 & 1 & 2 \\
\hline \multirow[t]{2}{*}{$\log ($ transfers $)$} & $0.470^{* * *}$ & $0.433^{* * *}$ & $0.467^{\star * *}$ & $0.373^{* * *}$ & $0.467^{* * *}$ & $0.416^{* * *}$ \\
\hline & $(0.047)$ & $(0.061)$ & $(0.050)$ & $(0.071)$ & $(0.047)$ & $(0.062)$ \\
\hline \multirow[t]{2}{*}{$\log$ (ownrev) } & $0.306^{* * *}$ & $0.212^{* * *}$ & $0.366^{* * *}$ & $0.230^{* * *}$ & $0.319^{* * *}$ & $0.217^{* * *}$ \\
\hline & $(0.041)$ & $(0.049)$ & $(0.048)$ & $(0.070)$ & $(0.042)$ & $(0.053)$ \\
\hline \multirow[t]{2}{*}{ Constant } & $4.008^{* * *}$ & $5.547^{* * *}$ & $3.291^{* * *}$ & $6.170^{* * *}$ & $3.878^{* * *}$ & $5.728^{* * *}$ \\
\hline & $(0.915)$ & $(1.074)$ & $(1.060)$ & $(1.450)$ & $(0.933)$ & (1.133) \\
\hline Year Dummy & NO & YES & NO & YES & NO & YES \\
\hline R-squared & 0.504 & 0.568 & -- & -- & -- & -- \\
\hline F-stat & 67.53 & 18.38 & 57.47 & 15.62 & 133.21 & 163.59 \\
\hline Prob $>$ F & 0.000 & 0.000 & 0.000 & 0.000 & 0.000 & 0.000 \\
\hline Observations & 136 & 136 & 136 & 136 & 136 & 136 \\
\hline
\end{tabular}

Source: Authors’ calculations. Note: ${ }^{\star *}$ shows significance level at $1 \%$ level, while values in parenthesis represent standard errors. 